\title{
MENINGKATKAN KETERAMPILAN PROSES SAINS DAN PRESTASI BELAJAR SISWA DENGAN PEMBELAJARAN GUIDED INQUIRY MODEL
}

\author{
Juli Sukimarwati \\ SMAN 6 Madiun, Jl. Suhud Nosingo No. 1 Kota Madiun 63139 \\ juli_sukimarwati@yahoo.co.id
}

Diterima 12 Januari 2017, Disetujui 28 Maret 2017

\begin{abstract}
The research objective is to improve science process skills and learning achievements of biology with Guided Inquiry Learning Model. The research subjects IPA3 class XI student of SMAN 6 Madiun number 34. This type of research is the Classroom Action Research (CAR) is conducted in three (3) cycles. Each cycle includes four stages: 1). Planning, 2) implementation of measures, 3) observation, 4) Reflection. Data were obtained from the observation of science process skills, and the value of student achievement based on post-test and daily tests. Test questions daily trials have been conducted to determine the validity, level of difficulty, and different power problems. Analysis technique used is descriptive analysis that includes: 1) Description of data, 2) Discussions, and 3) Conclusion. The results showed that the biology with Guided Inquiry learning model can improve sisw science process skills and learning achievement.
\end{abstract}

Keywords: guided inquiry model, the science process skills, academic achievement

\section{PENDAHULUAN}

Subjek utama dalam kegiatan pembelajaran berdasarkan panduan pengembangan penyusunan Kurikulum Tingkat Satuian Pendidikan (KTSP) tahun 2006 didasarkan pada prinsip bahwa siswa memiliki posisi sentral untuk mengembangkan potensinya, pembelajaran harus berpusat pada siswa (student centered). Kegiatan belajar mengajar yang selama ini dilakukan, sebagian besar berpusat pada guru (teacher centered). Guru lebih banyak memberi informasi, siswa kurang diberi waktu untuk mengemukakan ide-ide, memberi pengalaman-pengalaman abstrak, kurang memberi waktu untuk memecahkan masalah, serta pembelajaran homogen, hal ini menyebabkan rendahnya prestasi siswa di tingkat lokal maupun global.

Prestasi belajar siswa rendah merupakan permasalahan kompleks, baik kurangnya kompetensi guru dalam melaksanakan pembelajaran, yang menyebabkan motivasi belajar siswa kurang (Suparno, 1997). Guru sebagai pendidik profesional dengan tugas utama mendidik, mengajar, membimbing, mengarahkan, melatih dan menilai (Rustaman, 2007).
Seorang guru harus berwawasan jauh ke depan mengikuti alur perubahan dan pergeseran secara cepat yang terjadi pada kehidupan manusia khususnya dibidang pendidikan. Siswa perlu dibekali dengan kompetensi yang memadai agar menjadi peserta aktif dalam masyarakat, untuk kepentingan pribadi, sosial, ekonomi, dan lingkungan (Dahar, 1989).

Salah satu sekolah di Kota Madiun, yaitu SMAN 6 sebagai sekolah yang terletak di tengah kota sehingga menjadi salah satu alternatif pilihan sekolah untuk jenjang pendidikan menengah atas. Input siswa yang masuk sangat beragam, baik intelektual, kreativitas maupun motivasi berprestasinya. Prestasi belajar siswa SMAN 6 Madiun dapat dikatakan belum maksimal, yang terlihat dari perolehan nilai di setiap akhir Kompetensi Dasar (KD) masih banyak siswa yang harus menempuh remedial untuk mencapai KKM. Kompetisi di bidang akademik, SMAN 6 masih kurang dapat bersaing dengan SMAN lain di kota Madiun.

Kurang maksimalnya prestasi belajar siswa dapat disebabkan karena pembelajaran dikelas masih bersifat teacher 
centered, sehingga siswa tidak terlibat secara aktif dalam proses pembelajaran. Pendekatan dan model pembelajaran yang digunakan masih bersifat tekstual dan belum mengarah pada pencapaian pengetahuan konstruktivis dan kurang melibatkan sikap ilmiah siswa sesuai karakteristik materi biologi. Pelaksanaan pembelajaran sains (Biologi) yang terjadi masih dalam batasan penghafalan konsep, siswa kurang diajak ber-inkuiri yang melibatkan keaktifan sehingga siswa belum memperoleh pengalaman belajar yang beragam dan relatif lebih bermakna melalui keterampilan proses sains, akibatnya siswa kurang antusias dalam proses kegiatan belajar mengajar.

Berdasarkan kondisi nyata (real), fakta dan kondisi ideal di atas, untuk mengatasi agar siswa mampu berperan aktif dalam pembelajaran maka perlu adanya inovasi dalam menggunakan beberapa pendekatan, strategi dan model pembelajaran. Model pembelajaran memiliki peranan yang sangat penting dalam keberhasilan pendidikan (Piaget, 1971). Penggunaan model yang tepat akan menentukan efektivitas dan efesiensi suatu proses pembelajaran. Guided inquiry merupakan model pembelajaran yang menekankan dalam proses penemuan konsep. Model penemuan (inquiry) berusaha meletakkan dasar dasar dan mengembangkan cara metode ilmiah, dan menempatkan siswa lebih banyak belajar sendiri/kelompok untuk memecahkan masalah. Model pembelajaran penemuan mengembangkan keterampilan proses sains dan memusatkan perhatian pengembangan motivasi, dan kemampuan kreatif. Sehingga pada akhirnya dengan model pembelajaran ini keterampilan proses sains dan prestasi belajar siswa dapat meningkat. Tujuan penelitian adalah untuk meningkatkan keterampilan proses sains dan prestasi belajar dengan pembelajaran guided inquiry model

\section{METODE}

Jenis penelitian merupakan Penelitian Tindakan Kelas (PTK), dengan setting pembelajaran Guided Inquiry Model, yang bertujuan untuk meningkatkan keterampilan proses sains dan prestasi belajar kognitif siswa. PTK ini dilaksanakan dalam 3 (tiga) siklus, dengan pengambilan data tes prestasi belajar berupa ulangan harian. Setiap siklus terdiri dari tahap perencanaan tindakan, pelaksanaan tindakan, observasi, dan refleksi. Subyek penelitian adalah siswa kelas XI IPA 3 SMAN 6 Madiun.

Data diperoleh dari hasil observasi keterampilan proses sains dan data prestasi belajar diperoleh melalui post tes dan ulangan harian. Seorang siswa dikatakan telah tuntas keterampilan proses sains dan prestasi belajar apabila telah mencapai $\mathrm{KKM}=76$ dan daya serap kasikal mencapai $85 \%$ atau lebih. Prosentase keberhasilan keterampilan proses sains dianalisis menggunakan rumus :

$$
\frac{\text { Jumlah siswa yang tuntas }}{\text { Jumlah siswa seluruhnya }} \times 100 \%
$$

Penentuan taraf keberhasilan keterampilan proses sains dengan kriteria huruf, angka dan prosentase keberhasilan tindakan disajikan sebagaimana dalam tabel.1.

Tabel 1 Penentuan taraf keberhasilan keterampilan proses sains

\begin{tabular}{cccc}
\hline $\begin{array}{c}\text { Presentase } \\
\text { Keberha- } \\
\text { silan } \\
\text { Tindakan }\end{array}$ & $\begin{array}{c}\text { Taraf } \\
\text { Keberhasilan }\end{array}$ & $\begin{array}{c}\text { Nilai } \\
\text { Dengan } \\
\text { Huruf }\end{array}$ & $\begin{array}{c}\text { Nilai } \\
\text { Dengan } \\
\text { Angka }\end{array}$ \\
\hline 80 & Sangat Baik & A & 5 \\
$-100 \%$ & Baik & B & 4 \\
$60-79 \%$ & Cukup & C & 3 \\
$40-59 \%$ & Kurang & D & 2 \\
$10-39 \%$ & Sangat & E & 1 \\
$0-9 \%$ & Kurang & & \\
\hline
\end{tabular}

\section{HASIL DAN PEMBAHASAN}

\section{Deskripsi Data}

Penelitian Tindakan Kelas yang dilakukan terdiri dari 3 (tiga) siklus. Materi pada tiap siklus merupakan sub materi pada sistem peredaran darah, yaitu: siklus I. Darah dan Golongan darah, siklus II. 
Mekanisme sistem peredaran darah, dan siklus III. kelainan pada sistem peredaran darah. Data yang didapat dapat kami sampaikan sebagai berikut:

\section{Keterampilan Proses Sains}

Ada 8 (delapan) aspek yang diamati dalam keterampilan proses sains, masing-masing mempunyai skor maksimal 4 (empat) sehingga skor maksimal adalah 32. Keterampilan proses sains tersebut meliputi: a) Keterampilan mengamati, b) Merumuskan masalah, c) Membuat hipotesis, d) Merancang percobaan, e) Melaksanakan percobaan, f) Mengkomunikasikan hasil percobaan dalam bentuk tabel, g) Presentasi, dan h) Membuat kesimpulan. Tabel 2. Merupakan taraf keberhasilan tindakan ditinjau dari keterampilan proses sains pada siklus I, II, dan III.

Tabel 2. Taraf keberhasilan tindakan ditinjau dari keterampilan proses sains sikus I, II, III

\begin{tabular}{ccccc}
\hline $\begin{array}{c}\text { Siklus } \\
\text { ke }\end{array}$ & $\begin{array}{c}\text { Jumlah } \\
\text { siswa } \\
\text { yang } \\
\text { Tuntas }\end{array}$ & $\begin{array}{c}\text { Jumlah } \\
\text { seluruh } \\
\text { siswa }\end{array}$ & $\begin{array}{c}\% \\
\text { Keber- } \\
\text { hasilan }\end{array}$ & $\begin{array}{c}\text { Nilai / } \\
\text { Huruf }\end{array}$ \\
\hline 1 & 20 & 34 & $59 \%$ & C \\
2 & 25 & 34 & $74 \%$ & B \\
3 & 31 & 34 & $91 \%$ & A \\
\hline
\end{tabular}

\section{Prestasi Belajar}

Prestasi belajar diukur dari nilai postes yang diperoleh siswa selama kegiatan pembelajaran siklus I, II, III dan ulangan harian pada pertemuan berikutnya, diadapatkan hasil seperti pada Tabel 3.

Tabel 3. Nilai rata-rata post tes siklus I, II, III, dan ulangan harian

\begin{tabular}{|c|c|c|c|c|c|c|}
\hline \multirow{2}{*}{$\begin{array}{l}\text { Si- } \\
\text { klus } \\
\text { ke }\end{array}$} & \multirow{2}{*}{$\begin{array}{l}\text { Rata- } \\
\text { Rata } \\
\text { Nilai }\end{array}$} & \multicolumn{2}{|c|}{$\begin{array}{c}\text { Ketuntasan } \\
\text { Individu }\end{array}$} & \multicolumn{3}{|c|}{$\begin{array}{c}\text { Ketuntasan } \\
\text { Klasikal }\end{array}$} \\
\hline & & Sudah & $\begin{array}{l}\mathrm{Be}- \\
\text { lum }\end{array}$ & $\%$ & $\begin{array}{l}\mathrm{Su}- \\
\text { dah }\end{array}$ & $\begin{array}{l}\mathrm{Be}- \\
\text { lum }\end{array}$ \\
\hline I & 66 & 16 & 18 & & & $\mathrm{~V}$ \\
\hline II & 74 & 22 & 12 & & & v \\
\hline III & 81 & 30 & 4 & & $\mathrm{~V}$ & \\
\hline UH & 79 & 29 & 5 & & $\mathrm{~V}$ & \\
\hline
\end{tabular}

\section{Keterampilan Proses Sains}

Berdasarkan hasil observasi selama tiga siklus yang menggunakan Guided Inquiry Model diperoleh hasil bahwa hanya 59\% siswa yang menguasai Keterampilan Proses Sains (KPS) pada siklus I dengan taraf keberhasilan "Cukup" yang kemudian meningkat pada siklus II menjadi 74\% dengan taraf keberhasilan "Baik". Setelah dimantapkan pada siklus III meningkat lagi menjadi 91\% dengan taraf keberhasilan "Sangat Baik". Meningkatnya taraf keberhasilan ini menunjukkan bahwa siswa merasa senang dengan pembelajaran Guided Inquiry Model yang menerapkan metode ilmiah dalam setiap kegiatannya. Pada mulanya siswa masih bingung dengan menerapkan KPS dalam pembelajaran ini. Siswa harus dibimbing untuk membuat rumusan masalah, membuat hipotesis, Membuat rancangan percobaan. Siswa belum terampil dalam melakukan percobaan, masih malu-malu dalam mempresentasikan hasil percobaan, dan menyimpulkannya. Kesabaran dan ketelatenan guru sangat diharapkan dalam proses ini, guru harus mondar mandiri mendatangi setiap kelompok untuk memberikan bimbingan. Pada siklus II siswa sudah mulai menguasai KPS, dan pada siklus III siswa sudah menguasai Keterampilan proses sains seperti yang dituntut dalam Guided Inquiry Model.

Bertambah terampilnya siswa dalam melakukan keterampilan proses sains sejalan dengan apa yang dikatakan oleh Joice dan Weil (2000). Joice dan Weil (2000) mengemukakan bahwa model pembelajaran yang berbasis inkuiri adalah suatu proses melatih siswa untuk menginvestigasi dan menjelaskan fenomena yang tidak biasa. Pembelajaran inkuiri didesain sedemikian rupa agar siswa secara langsung melakukan proses ilmiah melalui tahapan metode ilmiah dan latihan dalam waktu singkat (Umar 2007 dan Brichman, 2009) Pembelajaran inkuiri dapat menghasilkan peningkatan pemahaman sains, produktivitas, berpikir kreatif, serta siswa diharapkan terampil dalam memperoleh dan mengolah informasi. 


\section{Prestasi Belajar}

Dari data prestasi belajar siklus I ketuntasan belajar individu hanya 16 siswa dengan ketuntasan klasikal 47,1\%, siklus II siswa yang tuntas belajar sebanyak 22 orang dengan ketuntasan klasikal 64,7\%, sedangkan pada siklus III terdapat 30 siswa yang tuntas belajar dengan ketuntasan klasikal 88,2\%. Demikian juga setelah diadakan ulangan harian terdapat 29 siswa yang tuntas dengan ketuntasan klasikal $85,3 \%$.

Berdasarkan data tersebut ketuntasan individu dan klasikal telah tercapai karena sudah mencapai $88,2 \%$ dengan $\mathrm{KKM}=$ 76. Ulangan harian juga telah mencapai ketuntasan klasikal yaitu sebesar 85,3\%. Memang ada penurunan dalam nilai ratarata kelas maupun ketuntasan klasikal, hal ini dapat dimaklumi karena materi Ulangan harian meliputi seluruh indikator yang yang didapatkan selama pembelajaran siklus I sampai siklus III, sedangkan nilai tiap siklus/Post tes hanya meliputi indikator dalam tiap siklus.

Kenaikan prestasi belajar kognitif siswa bisa dipahami karena model pembelajaran Guided inquiry ini berfokus pada proses berpikir yang membangun pemahaman mereka sendiri berdasarkan pengalaman yang mereka tahu. Pengalaman yang siswa dapatkan dengan bimbingan guru selama tahapan: merumuskan masalah, membuat hipotesis, merancang percobaan, melakukan percobaan, presentasi membuat kesimpulan, serta diberinya penguatan dan refleksi pada akhir pembelajaran (Kuhlthau, 2007). Potensi peningkatan prestasi belajar siswa ini sesuai dengan hasil penelitian yang dilakukan oleh: Schwarz \& Gwekwerere (2003), hasil penelitiannya menunjukkan bahwa siswa yang belajar dengan Guided inquiry terjadi perubahan koseptual. Selain itu hasil statistik menunjukkan peningkatan yang signifikan dalam post tes karena pembelajaran ini berfokus pada siswa yang terlibat dalam penyelidikan ilmiah.

\section{SIMPULAN}

\section{Simpulan}

Berdasarkan hasil pembahasan diatas, dapat disimpulkan bahwa: 1) Pembelajaran biologi dengan Guided Inquiry Model dapat meningkatkan Keterampilan Proses sains siswa, 2) Pembelajaran biologi dengan Guided Inquiry Model dapat meningkatkan Prestasi belajar siswa

\section{Saran}

Dari kesimpulan diatas kami dapat merekomendasi bahwa: 1) Guru bidang studi biologi hendaknya menerapkan Guided Inquiry Model untuk materi pembelajaran yang sesuai dalam upaya mengembangkan dan meningkatkan Keterampilan proses sains dan prestasi belajar siswa, 2) Pembelajaran menggunakan Guided Inquiry Model membutuhkan waktu yang cukup lama, sehingga guru harus mempersiapkan materi jauh hari agar dapat mencapai hasil yang maksimal

\section{DAFTAR PUSTAKA}

Brichman. (2009). Effects of Inquiry Lease - Learning on Students Science Literancy Shield and Confidence. International Journal for The Confidence of Teaching and Learning, 3 (2): 10-12.

Dahar, R W. (1989). Teori-teori Belajar. Jakarta: Penerbit Erlangga

Joice, B.R., \& Weil, M. (2000), Models of Teaching and Learning. Where Do They Come From and How Are They Used? In Models of Teaching (6th ed., pp, 13-28), Allyn and Bacon.

Kuhlthau, C, Maniotes, L, and Caspari, K. (2007). Guided Inquiry: Learning in the 21st century. London: Westport, Connecticut.

Piaget, J. (1971), Phychology and Epistemology. New York: The Viking Press.

Rustaman, N. (2007). Strategi Belajar Mengajar Biologi. Malang: Penerbit 
Universitas Negeri Malang.

Schwarz \& Gwekwerere. (2003). Using

A Guided Inquiry and Modeling

Instructional Framework (EIMA)

to Support Pre-service K-8 Science

Teaching.

Suparno,P.(1997).FilsafatKonstruktivisme dalam Pendidikan. Yogjakarta: Penerbit Kanisius.

Umar. (2007). The Effects of a Webbased Guided Inquiry Approach on Students' Achievement. Journal of Computers, 2 (5): 4-5. 